\title{
European Translation Studies as an Aspect of the Current Slavonic-Germanic Comparative Research
}

\author{
Viktoria S. Kniazkova ${ }^{1, a}$, Marina Yu. Kotova ${ }^{2, b,{ }^{*}}$ Marie Michlova ${ }^{3, c}$, \\ Olga V. Raina ${ }^{4, d}$, Olesya S. Sergienko ${ }^{5, e}$, Natalia V. Sivenkova ${ }^{6, f}$ \\ ${ }^{1}$ St. Petersburg State University, Universitetskaya nab., 7/9, St. Petersburg, 199034, \\ St. Petersburg, Russian Federation \\ 2 St. Petersburg State University, St. Petersburg, Russian Federation \\ ${ }^{3}$ Charles University, Faculty of Arts, Jan Palach Square 2, Prague 1, 116 38, Czech Republic \\ ${ }^{4}$ St. Petersburg State University, St. Petersburg, Russian Federation \\ ${ }^{5}$ St. Petersburg State University, St. Petersburg, Russian Federation \\ ${ }^{6}$ St. Petersburg State University, St. Petersburg, Russian Federation

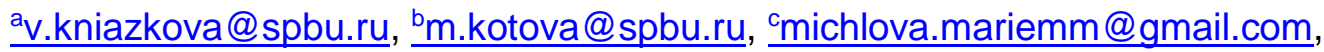 \\ o.raina@spbu.ru, ${ }^{\mathrm{e}}$ o.sergienko@spbu.ru, ${ }^{\mathrm{f}}$ n.sivenkova@spbu.ru \\ ${ }^{*}$ Corresponding author
}

Keywords: Slavonic-Germanic research, Translation studies, Bulgarian, Czech, German, Polish, Russian, Slovak.

Abstract. This paper is an attempt to reveal the major achievements of the comparative philological Slavonic-Germanic research conducted separately in six European countries during the last 20 years (1998-2018). The purpose of the paper is to show the main tendencies in the field of translation studies, based on the comparison of two language groups: Germanic and Slavonic. Using the bibliographical approach and synchronizing their efforts, the co-authors pointed out the special sides in each national area of translation studies.

\section{Introduction}

From the beginning of the 21st century Slavonic-Germanic comparative studies are among major scientific interests of the Department of Slavonic Philology at St. Petersburg State University. The Department was founded in 1835 and has got fundamental traditions. Today teaching of Slavistics at the three levels of university education - Bachelor of Arts, Master of Arts and Candidate of Science (equal to $\mathrm{PhD}$ degree) - is the practical realization of the philological research results: both in pure and in comparative Slavistics.

\section{Translation Studies as Typical Aspect of Slavonic-Germanic Comparative Research}

\subsection{In Bulgaria}

Bulgarian-Germanic comparative studies are held in two main directions: in the field of comparative linguistics and comparative literary criticism. Historically, the roots of Bulgarian comparative studies have been traced back to Russian / Soviet philology.

The results of the researches devoted to Bulgarian-Germanic comparative analysis of linguistic or literary phenomena contribute to Bulgarian translation studies. Dissertations or monographs on the subject are rather seldom. The studies do not look like a massive data, but a variety of scientific interests for comparison are very wide: from comparative analysis of the lexics by P. Legurska to questions of terminology discussed in the works of V. Georgieva and B. Aleksiyev. In 2009 an annotated bibliography entitled "Sypostavitelno ezikoznanie" was published [1]. 
Bulgarian comparative literary studies analyze deep phenomena in Bulgarian and English authors' novels and poems (B. Nichev, Z. Kozludzhov, A. Bakracheva, P. Stefanov, etc.). There are some studies that focus on the reception of a particular work or the entire work of a particular author (R. Rusev, N. Aretov), the other mention the influence of English-speaking authors on Bulgarian literature, for example, the Edgar Poe's influence on Bulgarian literature.

A huge flow of translated literature (mainly from English) still needs to be studied and described. The translation traditions of Bulgarian studies, including those related to the most difficult aspects of translation - the transfer of realities, the reflection of stylistic features, etc. are based on the well-known works of S. Vlakhov and S. Florin [2], S. Florin [3], I. Vaseva [4]. Very close to the translation studies are linguoculturology studies devoted to the language picture of the world. There are also works devoted to intercultural Slavic studies - in the field of imagology, geopoethics, gender disciplines, etc.

Among the newest Bulgarian translation studies are the monographs on general issues, for example the book of A. Dimova [5], the analysis of specifics of translation from Bulgarian, such as the research of T. A. Kirova [6], the methodological articles about the development of Bulgarian translation studies as a paper of A. Kh. Levi [7] and many others.

\subsection{In the Czech Republic}

In present time the Czech linguists differentiate comparative methods and translatology as separate fields of study. Translatology was established in Czechoslovakia even before the start of the WWII, some more modern approaches could be traced to works of Jan Mukařovský [8], and to works of Felix Vodička [9], who was a structuralist.

As for translatology as a unique scientific branch, Czechs owe much to Jiří Levý, whose work in Czech theories of translation [10] were especially useful. It was published in 1957 and soon after it was translated into many other languages, for example German and Russian, so it affected foreign academics too. This masterpiece, exploring various materials since the Medieval Ages, has never been surpassed and is still being used. Circa twenty years ago the Institute of Translation Studies [11] was founded at Faculty of Arts, Charles University. Now it shares the same building together with the Institute of Comparative Linguistics [12].

Czech translatologists gained a lot of worldwide reputations, especially academics such as M. Hrdlička, S. Rubáš, I. Ceňková and many others. They published a lot on many aspects of translatology, such as how to compare different translations of the same original, they also explore different styles of translation, and different types. Descriptive methods are very typical for Czech and Slovakian philology.

The new interactive database of Czech translators is being made by many researches and the team is lead by dr. S. Rubáš. The database aims to make a list of translators of fiction, who were active between 1945 and the present day. Now, it consists of a list of Czech translations from 82 languages, and it also contains information about the translators. It works in English too.

There is also an unfinished project of an encyclopaedia of the Czech translatology, it contains both biographical details and terms. It was supposed to be finished by 2016.

New anthology series called Tanslatologia Pragensia is published now, the articles are mostly in foreign languages, and they contain Czech abstracts.

It is very important for all translatology centres not to lose tight connections with other colleagues and teams from abroad. Czech translatologists keep especially in touch with Germany [13].

\subsection{In Germany}

In the 60 -s of the $20^{\text {th }}$ century in Leipzig prof. O. Kade founded a linguistic school of German translation studies. His theory has inspired many his followers in Germany and Austria and among them Austrian professor E. Prunč who in his monograph in 2012 demonstrated extremely diverse spectrum of the translatology problems even in comparative aspect of translation studies [14].

The analysis of topics of dissertations and monographs on translation studies, represented in the annual journal of German slavists "Bulletin der Deutschen Slavistik. Organ des Verbandes der 
Hochschulehrer fur Slavistik" allows to determine two special parameters of these fundamental works.

Firstly, Slavonic languages are mentioned in the titles of dissertations, monographs and dictionaries as follows: Russian (18 times), Czech (13), Polish (13), Serbian (2), Byelorussian (1), Bulgarian (1), Croatian (1), Slavonic languages (6).

Secondly, there are four thematic groups in these fundamental works: 1) theory of translation studies; 2) special grammatical and lexical problems of two-way Slavonic-Germanic translation studies (including dictionaries); 3) edition of new translations together with contextual comments and analysis of the reception in a foreign environment; 4) research about the reception of the translations of original works created in different periods.

Theory of translation studies is discussed in the works of several authors, e.g. C. Dathe; R. Makarska; Sch. Schahadat [15] and others.

Analysis of grammatical and lexical problems of bilateral translations is a sign of close connections between contrastive grammar and lexicology from one side, and translation studies on the other. To this group belongs a book of M. Nekula; K. Šichová; J. Valdrová [16] and others.

Edition of new translations with contextual and historical comments might be illustrated with editions of B. Lapin lyrics translations from Russian [17], translations from Polish of J. Kochanowsky [18] and others.

Some books deal with the reception of the poets and writers in translations: Russians F. Dostoyevsky, I. Goncharov, A. Griboedov, B. Pasternak; Czechs K. Čapek, V. Holan; Serbian D. Obradović; Germans W. Goethe, H. Heine, Th. Mann and many others.

German scholars are effectively cooperating with their colleagues from the Slavistics centres in Slavonic countries, this fact has to be taken into consideration during the analysis of their joint works.

\subsection{In Poland}

The Department of Comparative Literary Studies at the University of Warsaw was founded by Prof. L. Osinski in 1818, and it initiated the Slavonic-Germanic comparative studies. Professor E. Balcerzan devoted almost all his life to the theory of translation. His book "Translation as "world war". In the field of translation and comparative studies" (Tłumaczenie jako "wojna światów". W kręgu translatologii i komparatystyki) [19] devoted to numerous models, concepts and typologies that have permanently entered the scientific discourse of translation studies in Poland.

Polish scholars conduct different researches, that can be divided into several main trends: 1) translation theory and methodology e.g. K. Pisarkowa [20], 2) the history of translation e.g. M. Kaczorowska [21], 3) modern translation studies e.g. E. Tabakowska [22], 4) practical aspects of translation theory e.g. K. Hejwowski [23], 5) the history of translation of English or German writers into Slavonic languages [24], [25].

There are a few significant Polish journals essential for the development of Polish-Germanic translation studies, for example:

The magazine "Etnolingvistyka" (Ethnolinguistics) was established by Prof. J. Bartmiński - t he founder of the Lublin ethnolinguistic school. The articles about stereotypes and symbols in Polish, German and English have been published there.

"Cognitive Studies. Études cognitives" is an international and interdisciplinary scientific journal. It was formed by the Institute of Slavonic Studies of the Polish academy of sciences. There are articles related to contemporary linguistics, especially theoretical semantics in cognitive terms, lexical semantics, corpus linguistics, language confrontation of Slavonic languages and selected non-Slavonic languages (English, German).

"Rocznik Komparatystyczny" (The Comparative Year Book) is an international journal devoted to literary, cultural and intermedia comparative studies (since 2010). There are theoretical and methodical articles devoted to comparative studies, as well as comparative analysis of texts representing different cultures and disciplines, discussions on comparative monographs and reviews of monographs in Polish, English and German. 


\subsection{In Russia}

Translation studies in Russia concentrate mostly on linguistic questions. Linguistic theory of translation is viewed as one of the major divisions of linguistics along with other disciplines like comparative linguistics, psycholinguistics, sociolinguistics, cognitive linguistics, etc. which allows to apply linguistic methods in describing structural, semantic and cognitive aspects of translation [26].

Russian scholars conduct large-scale research that covers all problems of translation theory and methodology, translation criticism, the history of translation, modern translation studies both in Russia and abroad, as well as teaching translation and interpreting, machine translation, etc. The results of this research can be found in different scientific journals, e.g. "The Moscow University Herald", Series 22, Translation Theory or "Vestnik of Saint Petersburg University. Language and Literature". A comprehensive review analyzing achievements of the Russian theory of translation was recently published by Dr. Sc. Prof. Roman R. Chaykovskiy [27]. Rich bibliography of translation research in Russia as well as modern university textbooks and workbooks on English-Russian translation is offered in "Universitetskoje perevodovedenije" by V. I. Shadrin [28]. Burning issues of translation theory and practice are discussed at the annual International Philological Research Conference (Fiodorov Readings section) held at the St. Petersburg State University.

Here we concentrate on translation research conducted by Russian scholars based on the comparison of Germanic languages (English or German) and Slavonic languages.

While collecting bibliography of Slavonic-Germanic translation studies in Russia for the last 20 years, several factors became obvious. First, all the works were written in the last 10 years (2007 2017), not 20 years. Second, about seventy percent of such research was conducted at the Department of Slavonic Philology of the St. Petersburg State University either by faculty members or by their students in Bachelor and Master qualification papers.

Graduates of Czech-English, Czech-German, Slovak-English, Bulgarian-English and Polish-German Bachelor programs wrote 8 qualification papers on translation studies mostly devoted to the history of translation of Slavonic authors into English or German or English and German writers into Slavonic languages [29], or certain problems of translation practice [30]. Graduates of Slavonic-Germanic comparative studies Master program wrote 5 qualification papers concentrating on reception of Slavonic writers through English translations [31], translation of English inserts in the speech of Slavonic characters [32] and translation of paremiology and phraseology [33].

Since 2008 the problems of the reception of Slavonic culture in Germanic countries and issues of Slavonic-Germanic translation studies have been discussed on the regular basis at a designated section of the International Philological Research Conference organized at the St. Petersburg State University - in 2009-2011 it was called "Slavs in non-Slavic countries", from 2012 it is known as "Slavonic-Germanic comparative studies". This section united many scholars, and their enthusiastic collaboration resulted into two collections of articles "Slavs in non-Slavic countries" $(2010,2011)$ [34], a joint monograph "Segments of identity in the work of foreign Slavic writers" (2014) [35] and a few papers [36].

\subsection{In Slovakia}

Research of Dionýz Ďurišin in the area of comparative literature studies as well as works of Anton Popovič on translation studies in the second half of the 20th century were the most important contribution into the development of philology in Slovakia. The research by these two scholars resulted in the fact that Slovak comparative studies have been strongly connected with translation studies [37].

Today there are three centres of comparative research in Slovakia: The Institute of World Literature SAS, Constantine the Philosopher University in Nitra and Matej Bel University in Banská Bystrica.

Slovak comparativists' works have been inspired by the world trends highlighting culture and cultural identity [38], the proof being recent publications in the journal World Literature Studies, monographs and other works $[39,40]$. 
The research works on reception of foreign books in Slovakia as well as translations into Slovak have been versatile and profound [41, 42]. On the other hand, the attempt of analyzing reception and translation of Slovak literary works in the world has been made at Constantine the Philosopher University in Nitra. A researcher L'. Panisová published the monograph on Slovak translations into English in 2014 [43]. The next step was a collective monograph on translations of Slovak literature into other languages [44].

Comparative linguistics is mostly presented by works on Slovak-German language interaction and the influence of English on Slovak [45]. Slavonic-Germanic comparative studies in Slovakia have both a long history and a strong research base, but the scientific and academic interest towards literature studies has still been more profound. In spite of this fact, both areas of comparative and translation studies are in the process of development reflecting recent European trends.

\section{Conclusion}

Translation studies permanently attract all followers of Slavonic-Germanic comparative studies in Russia, Bulgaria, Czech Republic, Poland, Slovakia and Germany - a few European countries chosen by us for this survey. Various types of contributions to Slavonic-Germanic translation studies and a brief bibliography were shown here only in short to inspire widening of sources for language teaching and support for upcoming translation studies research.

\section{References}

[1] Asenova, P. Sypostavitelno ezikoznanie: anotirana bibliografiya: 1976-2009. Sofia, 2009. [in Bulgarian]

[2] Vlakhov S., Florin S. Neperevodimoe v perevode, Moskva, 1980. [in Russian]

[3] Florin, S. Muki perevodcheskie, Moskva, 1983. [in Russian]

[4] Vaseva, I. Stilistika na prevoda. Specifika na prevoda na razlichni vidove i zhanrove tekst. Sofia, 1989. [in Bulgarian]

[5] Dimova A. Uvod v teoriyata na prevoda. Shumen: Universitetsko izdatelstvo, 2001. [in Bulgarian]

[6] Kirova T. A. Temporalnite kategorii v chastnata teoriya na prevoda. Sofia : Marin Drinov, 2006. [in Bulgarian]

[7] Levi A. Kh. Teoria perevoda v Bolgarii // Vestnik PNIPU. Problemy jazykoznanija i pedagogiki № 8, 2013. P. 3-9. [in Russian]

[8] Mukařovský, J. Umělecké dílo jako znak (Z univerzitních přednášek 1936-1939). Ústav pro českou literaturu AV ČR: Praha, 2008. [in Czech]

[9] Vodička, F. Struktura vývoje. Odeon: Praha, 1969. [in Czech]

[10]Levý, J.: České theorie překladu. SNKHLU: Praha, 1957. [in Czech]

[11]https://utrl.ff.cuni.cz/.

[12] http://enlil.ff.cuni.cz/?q=frontpage.

[13]Übersetzung, Translation, Traduction: Ein internationales Handbuch zur Übersetzungsforschung. Mouton de Gruyter, Volume 1, 2004. [in German]

[14]Prunč E. Entwicklungslinien der Translationswissenschaft Von den Asymmetrien der Sprachen zu den Asymmetrien der Macht. Berlin: Frank \& Timme, 2012. [in German] 
[15]Dathe, C.; Makarska, R.; Schahadat, Sch. (Hgg.). Zwischentexte. Literarisches Übersetzen in Theorie und Praxis. Berlin 2013. [in German]

[16]Nekula, M.; Šichová, K.; Valdrová, J. (Hgg.) Bilingualer Sprachvergleich und Typologie: Deutsch - Tschechisch. Tübingen 2013. [in German]

[17]Belentschikow, V. Boris Lapins expressionistische „Hymnen gegen die Zeit“. Mit dem russischen Text und einer Interlinearversion von Ulrich Steltner. Frankfurt a.M. u.a. 2011. [in German]

[18]Daiber, T. Jan Kochanowski: Das Schachspiel. Übersetzung aus dem Polnischen, Textkritik, kulturhistorische Interpretation. Rugerup 2011. [in German]

[19]Balcerzan E. Tłumaczenie jako „wojna światów”. W kręgu translatologii i komparatystyki. Wydawnictwo Naukowe UAM, Poznań 2009. [in Polish]

[20]Pisarkowa, K. Pragmatyka przekładu. Przypadki poetyckie. - Kraków: Wydawnictwo Instytutu Języka Polskiego PAN. 1998. [in Polish]

[21]Kaczorowska, M. Przekład jako kontynuacja twórczości własnej. Na przykładzie wybranych translacji Stanisława Barańczaka z języka angielskiego. - Kraków: Universitas, 2011. [in Polish]

[22] Tabakowska, Elżbieta. Językoznawstwo kognitywne a poetyka przekładu. Kraków: Universitas, 2001. [in Polish]

[23]Hejwowski, K. Kognitywno-komunikacyjna teoria przekładu. - Warszawa: Wydawnictwo Naukowe PWN, 2004. [in Polish]

[24]Literatura niemiecka w Polsce. Przekład i recepcja/ pod red. E. Czaplejewicza i J. Rohozińskiego. - Pułtusk, 2009. [in Polish]

[25] Cetera A. Smak morwy. U źródeł recepcji przekładów Szekspira w Polsce. - Warszawa: Wydawnictwa Uniwersytetu Warszawskiego, 2009/ [in Polish]

[26]Universitetskoje perevodovedenije : uchebnik / V. I. Shadrin. - SPb. : BBM, 2017. P. 75. [in Russian]

[27] Chaykovskiy R. R., Light and Shadows of Modern Translation Studies in Russia // The Moscow University Herald, Series 22, Translation Theory, №4, 2016. P. 5 - 25. [in Russian]

[28]Universitetskoje perevodovedenije : uchebnik / V. I. Shadrin. - SPb. : BBM, 2017. [in Russian]

[29] Goma Yu. Yu. Bachelor thesis: Verbal means of creating artistic image in the stories by B. Hrabal and their English translations, SPbGU, 2012 (supervisor - dr. CSc. T. E. Anikina); Kapnina E. G. Bachelor thesis: Semantics of Czech colour naming and its English parallels (based on Milan Kundera prose and its English translations), SPbGU, 2016 (supervisor - prof. M. Yu. Kotova). [in Russian]

[30]Zolotova A. D. Bachelor thesis: Methods of translation of stylistic features of the Poles' speech based on Marina Lewycka novel "Two caravans" and its Polish and German translations, SPbGU, 2012 (supervisor - A. prof. O. V. Raina). [in Russian]

[31] Goverdova A. S. Master thesis: N. Vaptsarov in English translations, SPbGU, 2012 (supervisor prof. S. I. Nikolaev). [in Russian]

[32] Elfimova A. V. Master thesis: English inserts in a Czech text of the novel "The Engineer of Human Souls" by Josef Skvorecky and the novel English translation, SPbGU, 2010; Pazgalova L. A. Master thesis: Characteristic features of verbal communication of Slavic migrants in English-language surroundings (based on novels by Marina Lewycka and their translations into Slavic languages), SPbGU, 2013 (supervisor - prof. M. Yu. Kotova). [in Russian] 
[33]Fajer A. S. Master thesis: Methods of translation of proverbs and phraseological units from "The Lord of the Rings" by J.R.R. Tolkien based on its Czech and Russian translations, SPbGU, 2014 (supervisor - dr. CSc. O. S. Sergienko). [in Russian]

[34] Slavjane v neslavjanskih stranah. Vypusk 1 / otv. redaktor M.Yu. Kotova. SPb.: Fakultet filologii i iskusstv SPbGU, 2010; Slavjane v neslavjanskih stranah. Vypusk 1 / otv. redaktor M.Yu. Kotova. SPb.: Filologicheskij fakultet SPbGU, 2011. [in Russian]

[35] Segmenty identichnosti v tvorchestve zarubezhnyh slavjanskih pisatelej / Bodrova A. G., Brazgovskaja E. E., Kniazkova V. S., Kotova M. Yu., Raina O. V.; edited by M. Yu. Kotova. SPb.: Izd-vo S.-Peterb. un-ta, 2014. [in Russian]

[36] Kniazkova V. S. Enciphered toponyms in the German novel by I. Brezna "Die Beste Aller Welten" and its translation into the Slovak language, Philologicheskije nauki. Voprosy teorii i praktiki, Tambov: Gramota, №10(76): in 3 parts, P. 2, pp. 23-26, 2017; Sergienko O. S. Specifics of translating phraseological units (by the material of the novel by M.F. Bulgakov "Heart of a dog" and its Czech and English translations). Philologicheskije nauki. Voprosy teorii i praktiki, Tambov: Gramota, №4(58): in 3 parts, P. 3, pp. 144-148, 2016. [in Russian]

[37] Vajdová L., Ďurišin D. Preklad v porovnávacom výskume literatúr // Myslenie o preklade na Slovensku. Bratislava, 2014. P. 86-110. [in Slovak]

[38]Czech and Slovak Association of Comparative Literature // Litikon, vol.1, No.2, Nitra, 2017, pp. 121-123.

[39] Kultur im Transfer. Komparatistik in der Slowakei. Frankfurt am Main, 2016. [in German]

[40]Identity and Translation Trouble. Cambridge, 2017.

[41] Slovník slovenských prekladatel'ov umeleckej literatúry 20. storočie, A-K. Bratislava, 2015. [in Slovak]

[42]Pliešovská L', Od Buckovej k Updikovi. Americká literatúra na Slovensku v rokoch 1945-1968. Banská Bystrica, 2016. [in Slovak]

[43]Pánisová L., Slovenská literatúra v anglickom preklade - história a súčasnost' (1832-2013). Nitra, 2014. [in Slovak]

[44]Slovenská literatúra v preklade. Nitra, 2015. [in Slovak]

[45]Dobrík Z., Jazyky v kontaktoch (Anglicizmy a iné slová cudzieho pôvodu v nemčine a slovenčine). Banská Bystrica, 2007. [in Slovak] 